\title{
Petri dishes of an archipelago: the ecological rubble of the Chilean salmon farming industry
}

\author{
Andrew Gerhart ${ }^{1}$
}

\begin{abstract}
This article narrates part of the history of salmon flu in the Chilean salmon industry, and attempts to tie together environmental history and political ecology in order to reveal the complicated non-human and human collectives that constitute its "ecological rubble." It draws from ethnographic and archival research to show the views among salmon farm workers and local Chilotes who both supported and contested the industry in contradictory ways. Amidst a milieu of technocratic narratives of control, and blindness to nonhuman agencies, they themselves became simultaneously part of new forms of ecological rubble: hidden harms the industry brought to their archipelagic home. I argue that only through an awareness of these hidden collectives of both material and human social relations can we hope to weather the storms of production and destruction that industrial aquaculture births at sea.
\end{abstract}

Key words: environmental history, aquaculture, disease, agriculture, salmon farming, Latin America, Chile.

\section{Résumé}

Cet article raconte un morceau de l'histoire de la grippe du saumon dans l'industrie chilienne du saumon et tente de relier l'histoire de l'environnement et de l'écologie politique dans le but de révéler les collectifs non humains et humains complexes qui constituent ses décombres écologique. Il puise dans la recherche ethnographique et d'archives pour montrer les vues entre les travailleurs agricoles de saumon et Chilotes locales qui ont tous deux pris en charge et contesté l'industrie de façon contradictoire. Au milieu d'un milieu de récits technocratiques de contrôle, et la cécité aux organismes non-humains, ils devinrent eux-mêmes en même temps une partie de nouvelles formes de décombres écologique: les méfaits cachés de l'industrie a apporté à leur domicile archipélagique. Je soutiens que seulement à travers une prise de conscience de ces collectifs cachés de la fois matériel et des relations sociales de l'homme que nous pouvons espérer affronter les tempêtes de la production et la destruction que les naissances d'aquaculture industrielles en mer.

Mots clés: histoire de l'environnement, de l'aquaculture, la maladie, l'agriculture, l'élevage du saumon, l'Amérique latine, le Chili.

\section{Resumen}

Este artículo explica un pedazo de la historia de la gripe salmón en la industria del salmón en Chile y los intentos de unir la historia del medio ambiente y la ecología política con el fin de revelar los colectivos complicados no humanos y humanos que constituyen sus escombros ecológica. Se basa en la investigación etnográfica y de archivo para mostrar los puntos de vista entre los trabajadores de salmón y los chilotes locales que apoyaron y disputado la industria de forma contradictoria. En medio de un entorno de narrativas tecnocráticos de control, y la ceguera de los organismos no humanos, ellos mismos se convierten simultáneamente en parte de nuevas formas de escombros ecológica: daños ocultos de la industria trajo a su casa archipelágica. Argumento que sólo a través de una toma de conciencia de estos colectivos ocultos de

\footnotetext{
${ }^{1}$ Dr. Andrew Gerhart, Austin, Texas, USA. Email: gerhart "at" alumni.stanford.edu. I'm grateful for feedback by attendees of two workshops: the Transformations of the Earth workshop (Renmin University of China's Center for Ecological History/Rachel Carson Center), and Production and destruction, Latin American and Iberian Studies program, University of California at Santa Barbara. For valuable research assistance, I would like to thank Valeria Oyarzo of Chonchi, the Centro Latinoamericano para el Desarrollo Rural (RIMISP), Jonathan Proctor, Anne Winslow, and the entire staff at the Spatial History Lab, CESTA, Stanford University. I particularly thank Zephyr Frank, Richard White, Roz Naylor, and Roger Pasquier. This research was made possible through an Environmental Venture Project grant at the Woods Institute for the Environment, the Center for Food Security and the Environment, a Spatial History Lab Predoctoral Fellowship, and the Emmett Interdisciplinary Program in Environment and Resources, Stanford University. This is the first article in Javiera Barandiarán and Casey Walsh (eds.) 2017. "Production/destruction in Latin America", Special Section of the Journal of Political Ecology 24: 716-800.
} 
relaciones materiales juntos con las relaciones sociales humanas podemos sorportar a las tormentas de la producción y destrucción que la acuicultura industrial hace una realidad en el mar.

Palabras clave: historia del medio ambiente, la acuicultura, la enfermedad, la agricultura, el cultivo de salmón, América Latina, Chile.

\section{Introduction: the Chilean salmon flu}

Soy bastante categórico en afirmar que la enfermedad propiamente tal no existe en Chile.

[I am quite emphatic that the disease as such does not exist in Chile.]

José Miguel Burgos, Chief of Health, SernaPesca (Aquanoticias, 2001)

In the middle of June 2007, the largest salmon farming company in the world, Marine Harvest Ltd., reported a viral outbreak of something seemingly impossible at one of its sites off of the island of Chiloé in southern Chile. The 2 million fish at this particular salmon farming site were already sick in the usual way. They were recovering from a couplet of well-known, often co-occurring diseases: an infestation of an amphipod parasite called sea lice (Caligus sp.) which routinely eats penned salmon; and an outbreak of rickettsia (Piscirickettsia salmonis), a bacterium that colonizes the lesions that the sea lice have already excavated. $^{2}$ Sea lice, infamous in global salmon farming, have been a primary concern for the northern salmon farming industries since the earliest days of intense operations. Rickettsia, a bacterium endemic to the Americas, conspires with its host to plague salmon farming south of the Equator.

A combined outbreak of sea lice and Rickettsia was impossible to avoid at industrial salmon farming densities in Chile. The Chilean industry had become accustomed to losing many millions of dollars to the deadly combination - a standard operating procedure. Chilean salmon farmers budgeted for deterrents to offset their losses, and fought these losses with drugs. They started with insecticide baths using emamectin benzoate to kill the sea lice and to try to preempt the bacterial explosions. But since this was never very effective, excessive amounts of inexpensive but potent quinolone antibiotics were given to the salmon through feed, both as prophylactics and therapeutants. Quinolones are the same class of late generation, broad-spectrum antibiotics that are reserved by hospitals for use against the most serious human bacterial infections. The commonly prescribed "all-purpose" antibiotic Cipro is one example. Because of Rickettsia, Chile used enormous amounts, normally 300-400 times those of Norway, its rival industry. However, in 2007, Norway's per ton antibiotic use had reduced to $0.0008 \mathrm{~kg} / \mathrm{ton}$ of salmon, while Chile's use was 0.64 $\mathrm{kg} / \mathrm{ton}$, about 810 times greater than Norway's. In 2007 Chile put 387,000 kg of antibiotics into its marine environment; in 2014 it put 563,200 kg (Asche et al. 2010; Norwegian Institute of Public Health 2009; Esposito 2015).

On this June winter day in 2007, the divers and technicians at the Marine Harvest farm noted a strange and sudden 62\% increase in mortality among their already heavily medicated fish (Godoy et al. 2008). Instead of more infected sea lice lesions, something else was going on which they had not previously seen. Tens of thousands of lethargic fish were gulping for air at the surface of the pens. And tens of thousands more dead and dying fish showed ghostly transparent gills, swollen spleens and livers, and hemorrhaging in their bellies, kidneys, and swim bladders. The sub-contracted veterinarians eventually realized that the fish displayed the classic symptoms of a salmon disease thought impossible to exist in Chile: infectious salmon anemia (ISA), which also happened to be the first described fish influenza. Hampered by the normal diseases and drugs, these unlucky salmon would bear the distinction of dying from the first clinical diagnosis of infectious salmon anemia ever recorded in the southern hemisphere. All in all, about 272,000 adult salmon died at this initial site.

From this Marine Harvest site the disease attained the exceptional virulence for which ISA had already become famous in the northern hemisphere, although never to such effect as seen in Chile. Over the next six months it mysteriously hopped and skipped from farm to farm and crippled the entire Chilean

\footnotetext{
${ }^{2}$ Some $63 \%$ of the dead salmon were also infested with sea lice (Godoy et al. 2008; Mardones et al. 2011).
} 
salmon industry. A year later, 238 of 351 Atlantic salmon farms were infected in the southern regions of Chile, and tens of millions of salmon died. ${ }^{3}$ The industry immediately began firing workers in the $10^{\text {th }}$ region and moving production further south to the $11^{\text {th }}$ region. By 2009 over 20,000 people had lost their jobs, and the industry lost over US\$2 billion dollars.

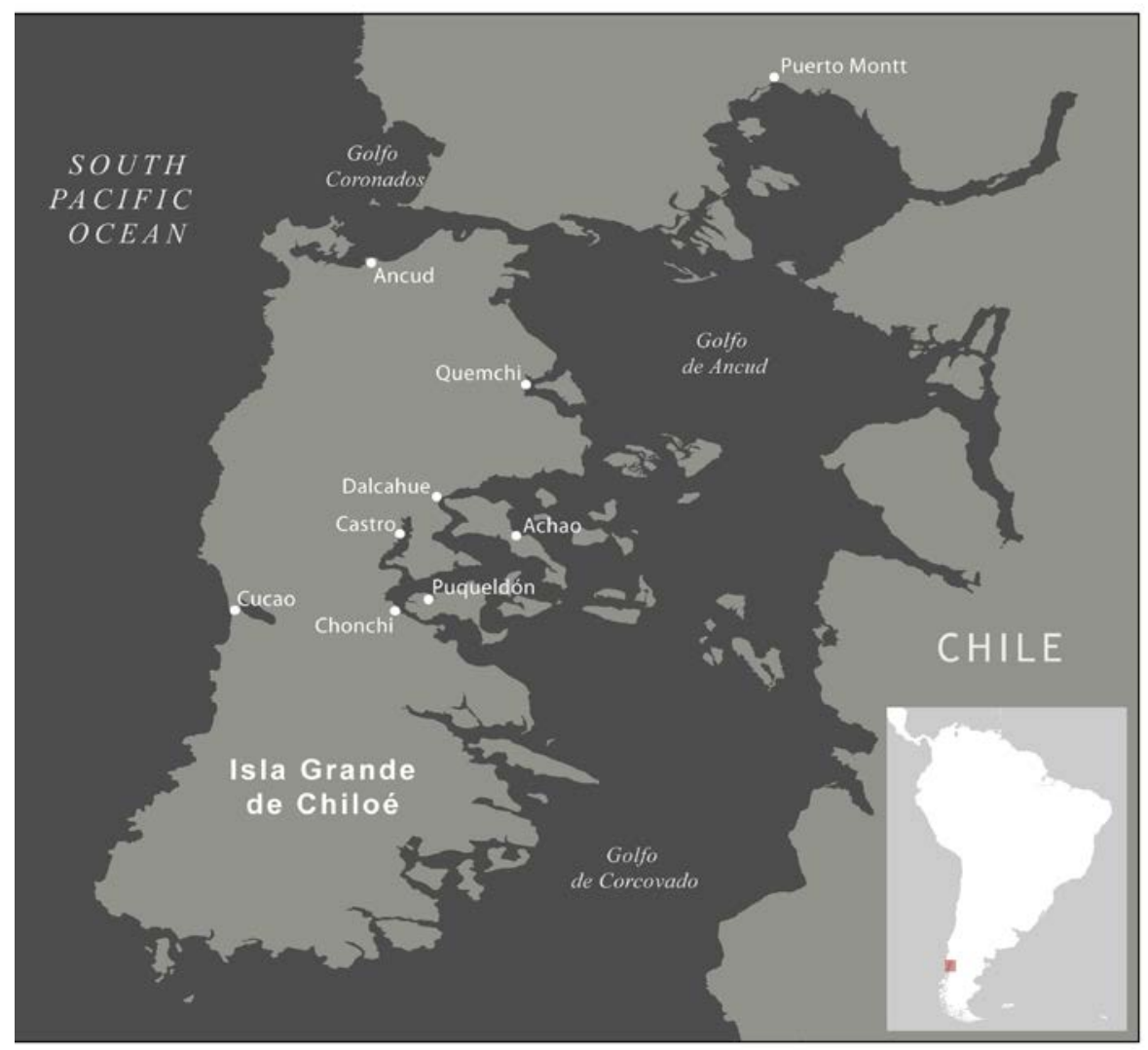

Figure 1: Chiloé and its location in South America. Source: Spatial History Lab, Stanford University.

\section{Situating cyclical failure and searching for ecological rubble}

Where does the Chilean salmon story fit amidst the longer opera of capitalist agriculture and its ecological rubble in the $19^{\text {th }}$ and $20^{\text {th }}$ centuries in Latin America and globally? Disease-ridden agriculture is nothing new to Latin America, especially in terrestrial plant agriculture. The efforts of governments and technical growers to establish ideological and practical control over nature, causing diseases in the process, has an extensive history beginning with the sugar plantations in Cuba and Puerto Rico of the 1910s and 1920s. When the mosaic epidemic threatened to ruin cane production, after monocultures expanded largely due to expansions of the railroad and ocean steamers, breeders succeeded in growing hybrid disease resistant varieties from Java (McCook 2002). These "liberal epidemics", as Stuart McCook calls them, are diseases resulting from the consequences of development strategies pursued by governments and wealthy elites (McCook 2011). McCook's story of the cane mosaic disease in Puerto Rico presents a particularly strong terrestrial parallel to the Chilean ISA story a century later. Like ISA's newly found virulence in Chile, the mosaic disease existed in many other country industries before devastating the Puerto Rican industry with

\footnotetext{
${ }^{3}$ Five of 128 steelhead trout farms (almon trucha) tested positive for the virus and were feared to transfer it, but were asymptomatic. Because of these fears, about 22 trout farms were either harvested prematurely or preemptively depopulated (Mardones et al. 2011).
} 
infectiousness previously unknown. Also, like the Chilean government denying the possibility that ISA could have spread to the southern hemisphere, mosaic disease scientists denied that the corn aphid, Aphis maidis, could transmit the disease in natural conditions, despite having demonstrated that it could in a lab.

John Soluri specifically compares ISA in Chile with the Panama disease fungus that blighted early 20th century banana production in the Caribbean. Soluri understands them as "commodity diseases", linking the Chilean salmon industry and its collapse through infectious salmon anemia to the Honduran banana industry and its struggle with many forms of plant disease on the grounds that both, as monocultures taking comparative advantage of environmental and labor conditions, "overdetermine" environmental outcomes in these industries and doom them to failure. In his recognition that bio-insecurity is a product of salmon farming just as much as other forms of industrial agriculture, Soluri's description of the insecurities of monocultures aptly characterizes the problems with Chilean salmon.

The fallacies in ascribing Chile's economic success to the neoliberal reforms for many of its export industries are well documented (San Martín 2017). Thomas Klubock has persuasively shown how Chile's forestry sector flourished only after a century of land dispossession, plantation development, and pulp processing, to the detriment of people and the environment (Klubock 2014). Heidi Tinsman has shown convincingly how the iniquilinos, Chilean peons, laid the foundations for Chile's grape boom well before the agrarian reform of the 1960s, and Pinochet's neoliberal reforms (Tinsman 2014).

These case studies inform the history of the salmon industry in Chile, to some extent. Like pulp and grapes, salmon had been imported from abroad to satisfy northern hemisphere consumers; it was in one respect the newest of these exotic commodities. And just as the mosaic disease in Caribbean sugar or the Panama disease fungus in Honduran bananas were the product of monoculture industries that bred exotic pathogens intensively, Chilean salmon farming did the same, resulting in the repaid spread of ISA. However, much has changed since the early $20^{\text {th }}$ century in Latin America, in directions that would seem to guard against "liberal epidemics" and "commodity diseases", but also in ways that reinforce their likelihood of reappearing. Environmental and labor NGOs have strengthened their capacities to study labor markets and environmental impacts that will be borne by both present and future generations.

Even if they were not responsible for economic success, neoliberal policies formed in the second half of the twentieth century did deregulate corporate behavior to an unprecedented extent. In Chile, the Pinochet government played a major role in ensuring that salmon firms could operate with virtually no oversight. This enabled an unencumbered technocracy to emerge, and with government support, to take complete ownership of riparian water rights to create freshwater pisciculturas. The government allowed the Chilean navy to grant protected aquaculture concessions to wealthy entrepreneurs from Santiago, and it established governmentfunded corporations like Fundación Chile.

Salmon were a high-value finished export that required significant technological capability and copious natural resources to produce. The industry built on the maritime skills of Chilotes, very experienced in fishing, and the processing capabilities of the beleaguered hake fishery. Finally, salmon were something Chileans, and even many Chilotes, were very proud of: a luxury product that was so exclusive that initially it couldn't even be sold in Chile (unlike beef production in Acre, Brazil: Hoelle 2017).

But what makes salmon so unique is the intensity of production, and the rapid growth and large scale of the industry. The densities of fish farmed in a space previously free from terrestrial norms of tenure or stewardship enabled rapid production of disease. In Latin America, the only historical precedent was Ecuadorian shrimp farming, another story that requires investigation.

This article seeks to tie the histories of human social relations with those of non-human actors in the unfolding of the environmental history of salmon, and to document the muddled, unintended, and highly contingent histories that modern global technocracies fail to acknowledge have changed the environment in irreparable ways. I attempt to apply, and extend, Gaston Gordillo's analytical framework to ecological concepts of living 'rubble' by asking: what constitutes the material evidence, both human and non-human, of ecological debris in a marine space? How can examining ecological rubble serve to clarify environmental histories? 
Gordillo documents how fetishization of ruins serves state and corporate elites by severing prior waves of destruction from our cultural memory. The concept of rubble works to unearth the past by reestablishing continuity with erased space, or in Gordillo's words, by examining "the places that were negated to create the geographies of the present" (2014:11). The concept of rubble thus fosters an awareness of the multilayered and contingent histories that modern stories about economic and technological development obscure, or in the case of Chilean salmon farming, flush out to sea.

The 'ecological rubble' in the salmon industry is the material wastes of fish, the residues of processing plants, and the ecologies of abandoned farmland, in addition to abandoned salmon farming infrastructures. There are also changes in peoples' lives. The impermanence of salmon farm-worker contracts; the transformed customs of Chilote potato farmers and shellfish harvesters leaving their lands and migrating to urban salmon processing areas; and the protests of these people against the devastation of the industry by salmon flu.

\section{Contesting rubble}

After simmering for years, protests flared in the immediate aftermath of the salmon flu. The leasing of large ocean concessions to the exclusive use of ever larger salmon and mussel farming companies had been a significant source of friction for many who had contested the industry, but particularly for existing artisanal fishermen. For these fishermen, watching the salmon industry take over their territory added insult to the injury of decades of endemic fishery failures. The Chilean government had earlier responded to the collapse of merluza or southern hake (Merluccius gayi) by instituting a set of quotas. But these were too small for local artisanal fishermen to survive. Stocks had been steadily decreasing, and the new policies had not managed to bring Chiloé's main fishery back after it collapsed in the 1980s. Having lost hake, locos (Concholepas concholepas), and sea-urchins, artisanal fishermen were now worried about local sierra (Thyrsites atun), cusk-eels, and mackerel populations that also were declining.

Differences in incomes fueled much of this anger. In 2008, while the Chilean minimum wage was US\$304 a month, the median monthly income of an artisanal fisherman in central Chiloé was US\$194 (96,666 Chilean pesos), which compared to US\$404 (201,250 Chilean pesos) for the median income of a salmon worker (Stanford-Rimisp Survey 2009). ${ }^{4}$ These differences were even more pronounced among rural Chilotes, where the median artisanal earnings were US\$150 a month, compared to median monthly salmon wages of US\$400 (Stanford-Rimisp Survey 2009). Without other job opportunities in rural areas, the frustrations of making less than half of the median salary enjoyed by salmon workers underwrote artisanal fishermen's protests. In urban areas, making less than the minimum wage did the same.

Beginning in the mid-1990s, artisanal fishermen had begun taking to the streets in public demonstrations to protest their loss of access to fishing. However, after the salmon industry had fully boomed by 2006, these protests grew, and their complaints became more varied. Cusk-eel (congrio) divers claimed escaped salmon devoured immature cusk eels and decimated its population. Groups of mussel farmers blamed salmon farms for polluting their shellfish beds and creating toxic red tides. When the Chilean government began imposing bans on shellfish collection amidst Chiloé's first red tides in the late 1990s and early 2000s, they began to blame the salmon industry for creating the dinoflagellate blooms that caused paralytic shellfish poisoning. These and other groups teamed up with former hake fishermen to protest the lack of attention their sector had received from regulators. They blocked entrances to salmon factories, regularly set ablaze barricades on major highways to stall transport vehicles carrying fresh salmon, and carried out hunger strikes.

By 2008, after the collapse of the salmon industry due to ISA, laid-off salmon workers joined artisanal fishermen and indigenous groups in ever-greater outpourings of criticism of the industry, particularly in rural areas (Figure 2). At first glance these protests seemed a bizarre amalgam of very different complaints working toward very different ends, only joined by the common need to voice anger. But many Chilotes who worked seasonally as operarios at salmon plants also worked the coastline as artisanal fishermen. Given the

\footnotetext{
${ }^{4}$ The survey was conducted in June and July of 2008, when the average exchange rate was 498 Chilean pesos/US\$. In October of 2008, the Chilean peso plummeted against the dollar to $625 \mathrm{Chp/US \$ ,} \mathrm{ending} \mathrm{the} \mathrm{year} \mathrm{at} \mathrm{647Chp/US \$ .}$
} 
complicated nature of work in the region, and the ensuing chaos after the salmon flu, these alliances made sense.

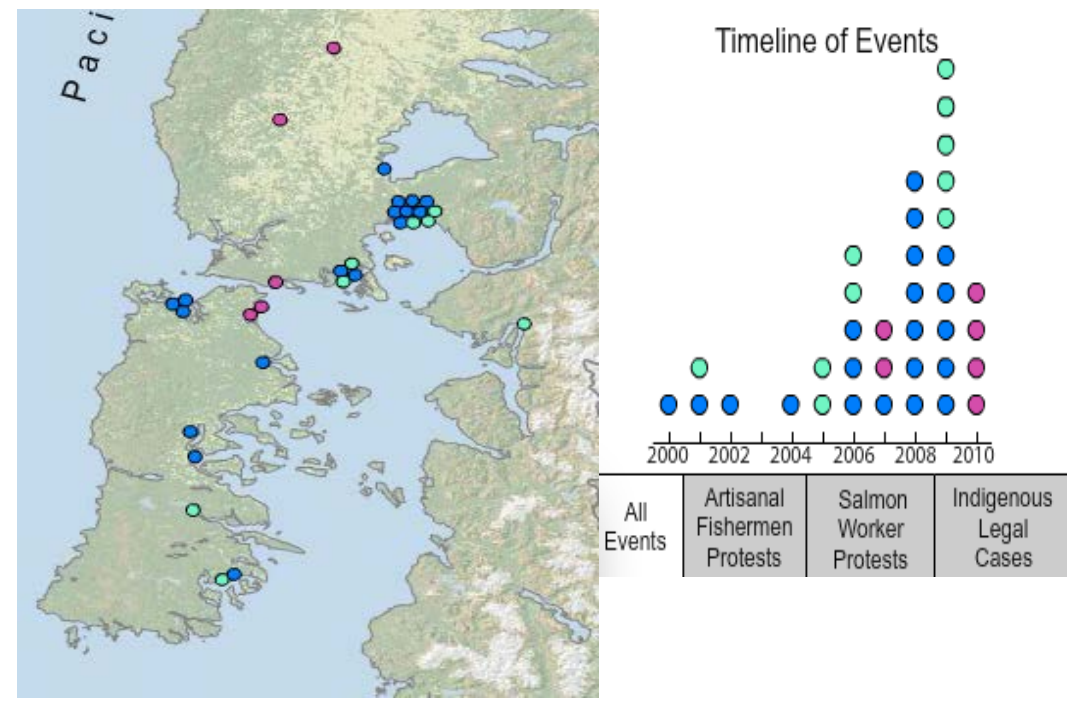

Figure 2: Protests around salmon flu, indigenous land tenure, and fishing, 2000-2010. Green: artisanal fishermen protests; Blue: salmon worker protests, Magenta: indigenous legal cases. Source: Anne Winslow and Andrew Gerhart, Stanford Spatial History Lab, CESTA, Stanford University. (Click on this weblink to view the visualization with individual case descriptions of protests:

http://www.stanford.edu/group/spatialhistory/cgi-bin/site/viz.php?id=359\&project_id=0)

Well before ISA struck in 2007, salmon industry workers had wondered how their wages were rarely above the legal minimum, how their collective bargaining could be so weak, and why so many permanent jobs were being replaced by seasonal ones without employment benefits or stability. Over time, they demanded more, and when negotiations failed in fragmented company-based unions, they went on strike. Occasionally these strikes led to wage increases, but more often they failed, and frequently the organizers were fired. The simple story told about the new and secure jobs that elevated standards of living for local Chilotes fizzled in the face of the challenges to the salmon industry. In place of a more secure environment that had invested work with permanence, benefits, and abundant opportunities, salmon industry jobs became perceived as less secure, both in terms of numbers as well as duration of contracts. This was all the more the case once the infectious salmon anemia took hold in 2007 and eliminated many of the remaining, and more highly valued jobs.

After ISA crippled the industry, labor unrest exploded as tens of thousands of layoffs occurred. More official strikes were called as the industry's profits shrank, and unions called for larger demonstrations to draw attention to their plight. The perception of the expropriation of Chilote resources for foreigners and multinational corporations had been a key stimulus for protests even before the salmon flu.

The complexity of concerns that fueled unrest was further enhanced by the global financial collapse of 2008. Chile's economic growth rate had hovered between 3 and 8 percent annually, but suddenly plunged to $-4 \%$ (Banco Central de Chile 2016). Thus, after ISA in April of 2009, when the Chilean Cámara de Diputados began discussing the Sandoval law, a set of environmental reforms to the 1991 Law on Fisheries and Aquaculture, the focus was not simply on preventing another crisis. This law, a response to the Infectious Salmon Anemia crisis, included controls on egg and smolt imports to reduce disease risk, granting concessions to salmon farmers in perpetuity, and barrios, or salmon neighborhoods of concessions where 
sanitary and environmental management periods are shared, including resting periods (Hosono et al. 2016). Soon, the trade association SalmonChile announced the move of its headquarters from Santiago to Puerto Montt just north of Chiloé to be closer to the industry. Two weeks later, in the early morning of May 4, the newly established headquarters were firebombed in the most aggressive symbol of protest against the salmon industry to date. An unknown anarchist group calling itself 'Comando Autónomo Tres de Mayo' took responsibility for the attack (Santiago Times 2009).

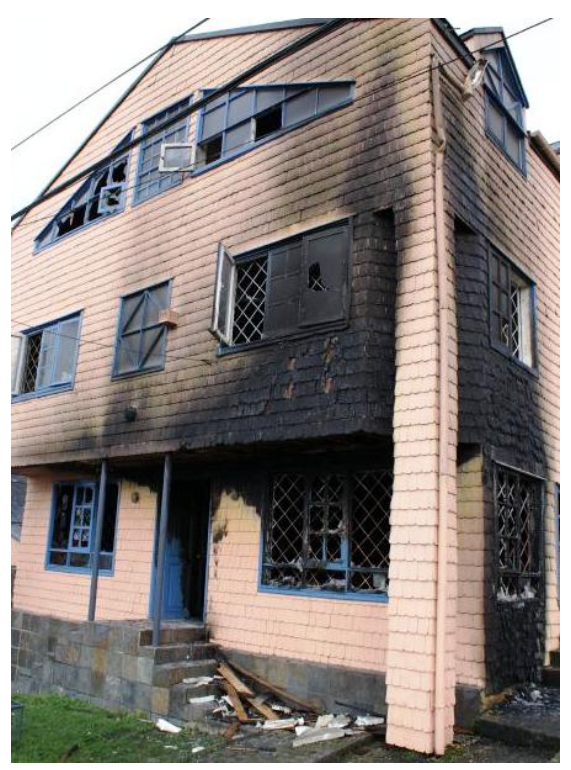

Figure 3: Fire-bombed SalmonChile offices in Puerto Montt. Source: El Llanquihue, May 5, 2009.

This bombing was significant because it symbolized a long-standing divide between the southern region and Chile's banking and investment elite in Santiago that had given birth to the industry in the 1980s and 1990s. The state, however, used it as a pretense to arrest critics of the industry. Three months later, on August 13, 2009, between 6 and 8 pm, armed police in riot gear searched the homes of 9 activists well known for opposing the salmon industry. These included the biologist, Hector Kol, and the trade union leaders, Jaime Bustamante (CUT) and Ricardo Casas. Casas was then president of the Federation of Fishing Industry Workers (FETRAINPES), as well as a member of the newly formed group 'Juventudes Libertarias.' Bustamante and Casas had been in Santiago the week before with a large delegation of labor leaders contesting the government's plan to give aid to only 5,000 salmon workers while the crisis was affecting over 20,000. The police raids confiscated computers, pen drives, CDs, clothing, paintings, books, photographs, and cameras. The deputy prosecutor responsible for investigating the SalmonChile firebombing, Sergio Coronado Rocha, authorized the raids. As no judge had issued the search warrants, the raids were illegal.

The very next day the Chilean Senate began its hearings in Santiago on the reforms to the industry that would soon become the Sandoval law (El Ciudadano 2009). Most of the discussion would be about bank liens on concessions for defaulting salmon farmers. However, the law's signature feature was the attempt to restructure with "species neighborhoods" that were intended to create disease barriers to protect against future outbreaks. Instead of placing salmon production or farm density limits on the industry, as Norway had done, all these reforms achieved was to rearrange concessions in the hope of creating species buffers in Chilean waters, so that future single-species diseases could not propagate throughout the entire industry. More importantly, in what clearly belied intent to expand the industry, it granted banks the right to own concessions given in common property waters in Chile for 25 years. This effectively legislated the privatizing of Chilean seas. As such, the Sandoval law resulted in an even faster consolidation of smaller 
firms that were unable to compete under the bank-controlled and legally designed monocultures dictated by the new regulations.

\section{Complicated cycles of nostalgia}

The infectious salmon anemia outbreak halted an economic boom that had embedded itself within Chiloé's local society since beginning experimentally in the 1970s, and growing exponentially in the early 1990s. When the crisis occurred, the ensuing protests represented anger at the loss of an economy, but also at local perceptions of cultural loss, regional perceptions of cultural autonomy, and international perceptions of modernity and prestige.

Immediately, Chilotes looked back at the industry with nostalgia. The complicated atmosphere surrounding the protests against the salmon industry resulted from the fact that initially most Chilotes were not upset about salmon farming. Regardless of its job insecurity or its environmental problems, it brought people steady jobs. Also, as an enormous source of foreign exchange grown at home, some Chilotes felt pride in an industry that fed a new sense of Chilean nationalism previously foreign to Chiloé, which had always been culturally isolated from Chile (Hayward 2011). However, most of these were Chilotes who had moved back to the island from the Chilean mainland to farm salmon.

Locally, job security had anchored those who supported the industry. Jobs with stable incomes, however meager, trumped the risks many other more traditional Chilote jobs offered, such as the artisanal fisheries or subsistence agriculture. By the end of the 1990s, for example, a diver collecting sea urchins and spearing cusk-eel might earn as much as $\$ 40$ a day, three times as much as a salmonero. Yet time spent diving was risky and earnings were never guaranteed, particularly as local shellfish and urchin beds became depleted. Some days divers came back empty-handed after a grueling day of twelve hours in 50-degree $\left(10^{\circ} \mathrm{C}\right)$ waters. When they did bring home a catch they were held captive to fluctuating prices and the middlemen who travelled the beaches buying for foreign markets. ${ }^{5}$

Salmon farms became an attractive alternative to the traditional Chilote lifestyle of sheep and potato farming and artisanal fishing. They were perceived to guarantee a wage for a much shorter workday, and relatively easier work. Even though salmon farms hired and fired seasonally to avoid paying benefits, the jobs they provided were still welcome for the short-term consistency in income they allowed. When fired from the salmon farms, Chilotes would return to the precariousness, but independence, of the sea; for those who had not moved to cities, they could spend more time working their farms. For those that had, they would try to find work where they could, but frequently drifted to the next salmon farm or factory (Figure 4).

Over time, as working life in the salmon factories changed dramatically, the perception of job security changed with it. Technology that trickled into Chile would gradually eclipse the comparative advantages of inexpensive labor in Chile. In the mid-1990s, automated feeders began to be used, and by the turn of the century, most of the technologies widespread in the northern hemisphere were standard in Chile. Eventually feed was delivered from floating storage tanks by timed computers and automated blowers, and underwater cameras monitored fish behavior to feed fish more efficiently. Far fewer workers were needed to watch the monitors and dive the net-pens to collect the inevitable pile of rotting morts, or fish carcasses, at the bottom.

Technology would replace work and transform what roles remained into relatively skilled positions that took men out to isolated pens for 10 days at a time, far from their families and their homes, and bored for lack of diversion. ${ }^{6}$ At the end of the 1980s a farm with net-pens raising 250 metric tons of salmon employed over 60 people. A decade later, the same centro de cultivo averaged 1,000 metric tons of salmon with 14 workers. And by the twenty first century, as automated feeders became standard, that centro grew 2,000 metric tons with just 4 men. The amount of salmon produced skyrocketed by a factor of 50, but the average number of tons a salmon worker produced rose far more, going from 4 to 500 in just fifteen years. The result was a highly technical industry that, while becoming Chile's third most valuable export through the enormous

\footnotetext{
${ }^{5}$ Japanese wholesale prices for sea urchin roe at Tsukiji market in Tokyo fluctuated between \$33/kg in1986, \$68/kg in 1995, and $\$ 42 / \mathrm{kg}$ in 2002. Chile has been the largest producer of sea urchins in the world since 1993 (Sonu 1995).

${ }^{6}$ Interview with Sr. Tito, February 26, 2010.
} 
of expansion of profit margins, did not provide nearly as many new jobs as the tons of salmon it produced led people both in Chile and North America to believe. ${ }^{7}$

Nonetheless, on a local scale, although work in salmon was viewed as ever more precious, it was sorely missed after the salmon flu. Salmon was certainly the biggest single industry that was part of the income distribution in Chiloé. The average Chilote interviewed in 2009 was keenly aware of the promise for income generation that the industry had brought, and very few people did not want the industry back in Chilote waters in the wake of ISA. Despite the critiques of the industry, the value of steady jobs from salmon farming was overwhelmingly apparent in Chiloé after the salmon flu, and continues to be. This was confirmed by the Stanford-Rimisp survey results, where $78.1 \%$ of all respondents answered that the salmon industry was either 'very beneficial' (63.8\%) or 'moderately beneficial' (14.3\%). Only $11.3 \%$ said it was negative. Even among households who had never benefited from work in the salmon industry, $75.6 \%$ found the industry beneficial and $12.6 \%$ found it negative. Predictably, $85.5 \%$ of households that worked in salmon found it beneficial, while only $8.3 \%$ found it negative (Stanford-Rimisp 2009).

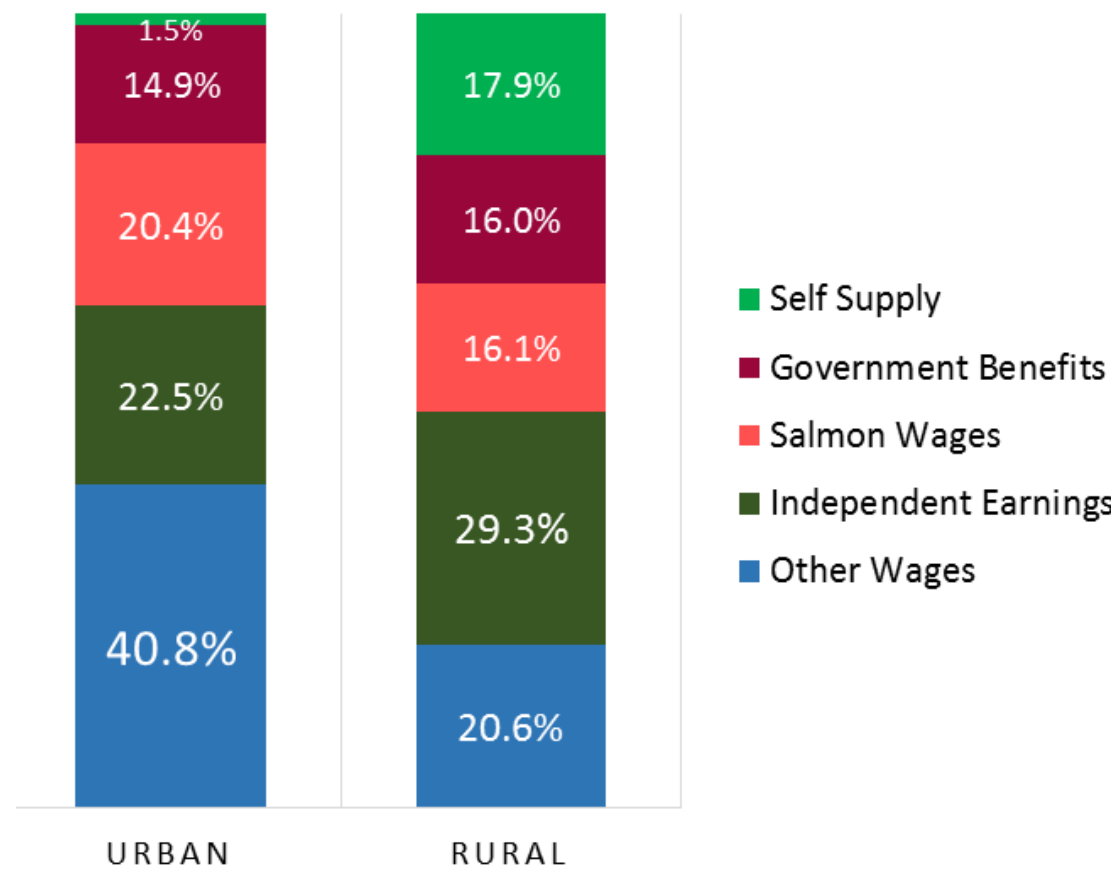

Figure 4: The importance of salmon income among urban and rural households in central Chiloé, 2008. Source: Stanford-Rimisp Survey, 2009.

A mid-level salmon farm site manager, reflecting on whether the salmon farms should return to Chiloé after fleeing ISA, highlighted the lack of education to prepare them for jobs outside the industry, or opportunities for retirement among his people:

\footnotetext{
${ }^{7}$ See Bluth et al. for averages (2003: 167). In one interviewee's example, the Chilean company Salmones Puntra in 1988 had 36 workers managing 10 salmon cages each 10 x 10 meters in size, each holding 5,000-10,000 salmon. In 1995 it was sold to a Turkish businessman, Ramón Neblen, became Salmones Chonchi, and employed only 30 workers, despite growing in volume to 48 cages, each $20 \times 20$ meters in size, each with 20,000 fish in them. In 2000, it was sold to Mainstream, the Norwegian state-held company, where cage sizes would grow to $30 \mathrm{x} 30$ meters by 2005, each with 30,000 to 60,000 salmon, employing only 15 workers.
} 
... it would be good if the salmon farming returns because the people are going to have work again, clearly they are not educated... and like my mother, no one has a retirement anymore, no one... ${ }^{8}$

This man was the only native Chilote surveyed who was in a managerial role at his salmon company, which was the largest Chilean company in the industry. In order to keep his job he left the island, about a 6hour round-trip drive and ferry, for many days at a time. As a native Chilote, he knew how much the work meant to the Chilotes working the farms. If rare compared to the early days, when jobs were more certain and more secure, these jobs were all the more valuable and desired by Chilotes, even if Chilotes rarely filled them anymore.

These Chilote impressions of the value of the salmon industry in Chiloé were all the more remarkable given that individual salmon jobs were harder to come by, and job security in the industry had fallen. The industry had transformed into a modern, technical and highly globalized industry that provided fewer permanent jobs, and relied more and more on foreign capital and seasonal and subcontracted labor. Although aggregate numbers of jobs increased industry-wide, local perceptions of job insecurity also increased as the industry became more mechanized. Despite the fact that newer and better machines continued to replace people, and salaried contracts became fewer and fewer, salmon jobs were still very good jobs. Also, side by side with technological changes, institutional shifts slowly occurred as Chilean laws caught up to working conditions and the labor movement exposed various abuses. In this environment, most Chilotes were nostalgic for the easier boom days of salmon. Yet this was a nostalgia complicated by the damage salmon farming had already done to local Chilote society in shifting rural livelihoods to urban ones. It was a nostalgia that ran up against a slowly dawning awareness of the ecological rubble of the industry.

\section{The invisibility of ecological rubble}

It seems paradoxical that at a time when we have managed to control or even eradicate major human virus infections like polio and smallpox we are increasingly confronted with new or newly emerging virus infections of humans and animals. A complex mix of social, technological and ecological changes, and the ability of certain viruses to adapt rapidly to a changing environment, seems to be at the basis of this phenomenon.

Albert Osterhaus, Philosophical Transactions of the Royal Society (2001)

No explanation grounded in the universalizing force of human projects and intentions can explore whether the very possibility of the human, of intentionality, of abstraction depends on, at the same time as it overlooks, nonhuman elements. These appear merely physical, secondary, and external.

Timothy Mitchell (2001: 23)

These two quotes, along with the one that opens this article, were all published in the same year, and demonstrate distinct frames for thinking about the possibility that the first described fish influenza might have existed in Chile as early as 2001, six years before the crisis that would buckle and redefine the Chilean salmon farming industry. The opening quote by José Miguel Burgos, currently the head of Chilean fishing authority SernaPesca, registered the state's purported certainty that the virus could not be behind the breakout. When Burgos spoke, Guata amarilla, as it was known in Chile, was an unknown salmon disease that genomic analyses by salmon virologist Fred Kibenge in Canada had just revealed was identical to ISA. For Burgos, and the state he represented, it simply was not possible to admit that the fish flu, well known in northern hemisphere salmon industries, could have mysteriously crossed the equator to travel over 100 degrees of latitude to reach southern Chile's booming industry.

\footnotetext{
${ }^{8}$ Interview with Sr. Ramirez, March 7, 2010.
} 
The second quote is by one of our foremost living virologists, the Dutch expert Albert Osterhaus. He expresses his awareness of environmental triggers for viral mutation, but also his amazement that humans, having conquered the pathogens of our past, could be incubating new viruses at the rates that were still being seen in the 1990s. Osterhaus was the first to describe the link between humans and the deadly H5N1 bird influenza, but seems unable to fathom the complexity of new virus creation when this is paired with the "paradox" of previous eradication. His professional existence depends on the promise of eradicating emerging viruses just as much as it depends on the production of new ones. So the paradox he described underwrites his profession and his investments in pharmaceutical companies he had co-founded. ${ }^{9}$

The third quote, by the political theorist Timothy Mitchell, critiques social theory that imparts intentionality and human rationalization to an understanding of economic and societal development. Separating the human and non-human spheres of influence without acknowledging the agency of non-human actors results in an analytical blindness common among social scientists. This blindness is akin to Burgos' blindness about the possible existence of ISA in Chile in 2001, and the blindness of a technocrat like Osterhaus to the reality that science has not and cannot control known pathogens, that human social relations embedded in an industrial economy will not breed new ones.

Without recognizing the complexity of non-human agency, the sources of ecological rubble are not understood, even when they hybridize with human protests. Overly simplistic narratives that attempt to justify current power structures come in many types. Chilean salmon farming reveals two: political narratives that veil environmental destruction, and purported paradoxes that serve to protect those in positions of technocratic power. Both types are simplifications that seek to hide manufactured risks and prevent challenges to a discourse of technical progress reliant on cycles of booms and busts. Collapses foment economic and scientific opportunities that the wealthy and politically powerful can exploit through technical solutions. These inevitably lead, however, to new problems that in turn require new solutions in a continuing accelerated cycle that orchestrates a charade of human intention and control (Brantz 2011; Curran 2013; Dumit 2012; Giddens 1999).

Chilean salmon farming, as a hyper-intensive form of industrial aquaculture with highly confined, extremely dense production, and high rates of disease, is an excellent example of an industry that promotes these boom and bust cycles. By promoting the accelerated mutation of new pathogens, both spatially and temporally, Chilean salmon farming continuously requires epidemiological breakthroughs as hyper-densities generate new diseases and enable broader infections to transfer across species to wild fish. This is amplified in a corporate environment with lax regulations; investors exclusively motivated by short-term profits are in control of the information regarding disease creation, accumulation, and dissemination. In such an environment, epidemiologists have neither incentive nor resources to prevent disease, and governments lacking information cannot be useful. Ultimately, the rubble from these disease busts falls to the sea-bottom as new booms take shape. How can we see it under the waters of new and reinvented marine landscapes? Could ISA, the first known fish flu, ever mutate to infect humans in these petri dishes along the Chilean coast?

In the wake of the salmon deaths and the worker lay-offs from ISA, Chile's total production of Atlantic salmon stagnated for a few years, but the bust was not felt by the industry at large as painfully as it was locally in Chiloé. Because of the lag in the production cycle, 2010 was the worst year, with only 123,000 metric tons of farmed Atlantic salmon, less than a third of what it had harvested in 2008. Norway capitalized on the crisis. Both the price of salmon went up due to the ISA crisis, and Chile was unable to keep up with demand in its main market of North America, so Norway captured a large amount of Chile's market share in the U.S. When it became clear from genetic analysis that a strain of ISA had been transferred to Chile through Norwegian salmon eggs, members of the Chilean congress accused Norway of intentionally sabotaging the Chilean industry (Aquanoticias 2009).

The Chilean industry actually rebounded relatively quickly, shifting much of its production further south to less densely farmed waters, and then returning production to Chiloé in the wake of the Sandoval

\footnotetext{
${ }^{9}$ Osterhaus is the cofounder and "chief security officer" of ViroClinics B.V. a company which sold 34 million viral H1N1 vaccines to the Dutch government during the scare of swine flu in 2009 (NRC Handelsblad 2009).
} 
laws. Monitoring for ISA was mandatory and as ISA recurred, infected farms were immediately quarantined. By 2014, Chile was back at historic production levels, producing nearly 650,000 metric tons of Atlantic salmon, and nearly 950,000 metric tons of all species of farmed salmon (FAO 2016). Despite greater production, however, few jobs returned to Chiloé, as the industry continued to mechanize. Even fewer jobs returned to native Chilotes, as better-trained outsiders took the jobs that remained.

The industrial effort to remake salmon rubble invisible was in high gear. Epidemiologists received far more funding from Chile's national science funds, FONDECYT and FONDEF, than environmental scientists studying red tides or exotic invasions (Lizana 2016). The industry's designs on the sea-space had salmon companies holding onto almost all of the concessions available, and leaving them fallow, in the hopes of continued expansion, and many concessions were not located near actively farmed salmon pens. Figure 5 shows how the industry expanded into the south and leased concessions speculatively as it grew. Now there are dreams of integrated multi-trophic aquaculture with giant brown kelp (Macrocystis pyrifera) that can be grown from salmon farm wastes and that can be converted into biodiesel. There are already grids upon grids of mechanized mussel farms dotting the horizons of the archipelago.

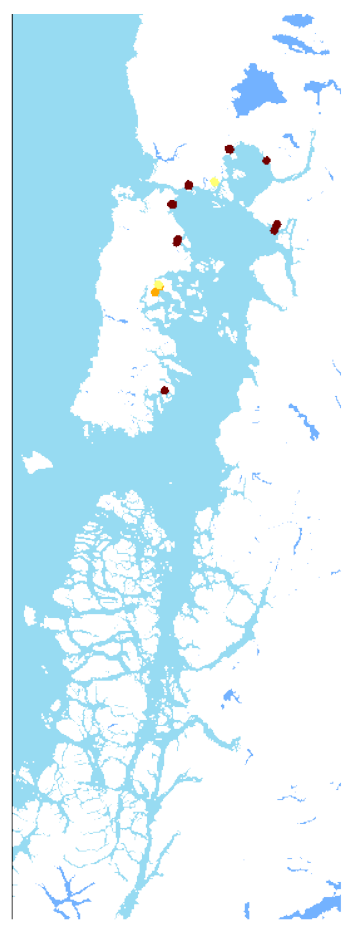

1985

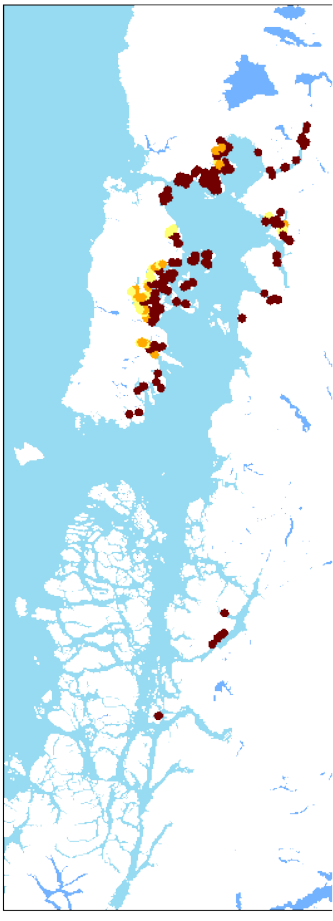

1991

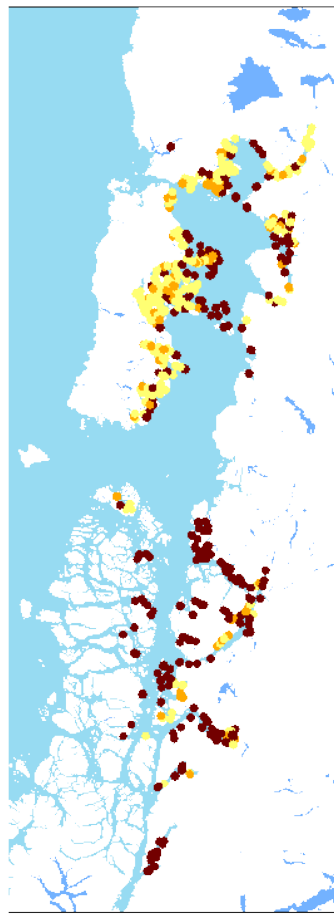

2000

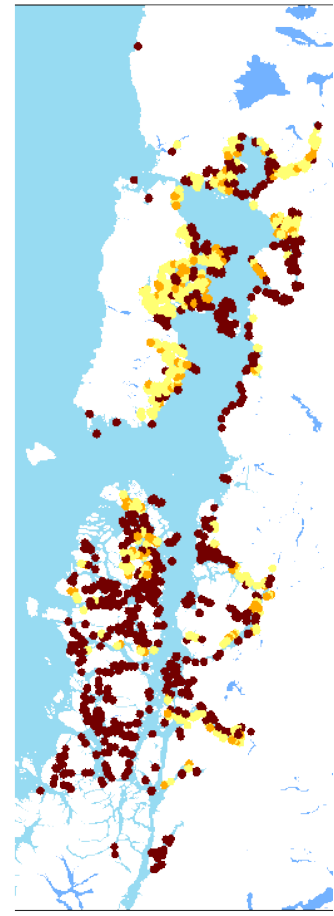

2006

Figure 5: Speculative salmon concessions by year. Colors represent the distance from concessions to nearest actual pens: yellow $0-1 \mathrm{~km}$, orange $1-3 \mathrm{~km}$, red concessions are greater than 3km from an existing farm; historical Google map images were used to make calculations. Source: Jonathan Proctor and Andrew Gerhart, Stanford Spatial History Lab, CESTA, 2012.

In the spring of 2016, a new actor emerged on the main-stage drama of Chilean salmon farming: the red-tide causing dinoflagellate (Alexandrium catanella). It had been known to cause smaller red-tides in Chile since 1972, but this year 23 million salmon, comprising 100,000 metric tons, suffocated to death in their net-pens. Constituting the biological rubble of a nexus of intensive animal agriculture and climate change, the algal blooms were also associated with an enormous die-off of clams on Chiloé, as well as a die- 
off of 8,000 tons of sardines along the coasts just north of the island. There was also speculation that the deaths of 337 Sei whales south of Chiloé, in one of the largest whale strandings in history, were associated with the algal blooms (Franklin 2016; Howard 2015).

A set of events similar to the ISA crisis from 2007-2008 immediately ensued. The industry lost nearly a billion dollars and confronted a crisis of nearly the same magnitude. However, the extent of the crisis went even further in Chilote society because the government placed harvest restrictions on artisanal fishing for the entire archipelago to avoid paralytic shellfish poisoning tainting Chilean exports. When the government offered to compensate artisanal fishermen with 100,000 Chilean pesos per affected family ( US \$200), the artisanal fishing community took to the streets en masse throughout Chiloé. Beginning on May 3, protesters blocked all transport (except EMS vehicles) on and off the island, and throughout the island. The protests were largely peaceful, and widely supported by Chilotes, lasting until May 19, when fishermen agreed to a compensation of 750,000 pesos per family ( US\$1,500).

The protestors claimed that the industry's dumping of dead salmon out at sea under the guidance of SernaPesca had caused the massive red tide that affected the shellfish. It is not completely clear how much was dumped, but there were reports that 4,000-9,000 tons of salmon were discarded 75 nautical miles offshore. Since only one third of the 100,000 metric tons of dead salmon were buried in landfills, this leaves about 60,000 metric tons of salmon carcasses unaccounted for.

Marine scientists believe that the massive red tide is linked to the very strong El Niño signal that blanketed the world's oceans that year, because raised sea temperatures correlate with stronger algal blooms and red tides. Many also acknowledge, however, that high nutrient loads are necessary for algal blooms of this scale, and cite the enormous wastes generated by salmon farming as a likely contributing factor. The ecological rubble produced by the industry may have co-acted with the Alexandrium dinoflagellate and El Niño to cause these die-offs. And to the extent that El Niño may be exacerbated by climate change, a relationship poorly understood, local and global forms of ecological rubble might have abetted each other to leave an estimated more than 10,000 people out of work: 5,000 artisanal fishermen, 4,000 salmon farm workers, and 2,300 indirect workers (Undercurrent News 2016). Now the government is trying to make new regulations to place finite density limits on salmon farms, with limits on the overall numbers that individual farms can grow. But the companies are now suing the government, as they also go back to the banks to try to renegotiate the US\$1.25 billion in debt that matures for them in the next 12 months (Diario Financiero 2016).

\section{Conclusion: hybridized collectives of ecological rubble}

There still seems to be little awareness in Chile of the precarious nature of the disease regimes in salmon farming, and so the rhythms of destruction continue in the industry. Despite the barrios set up by the Sandoval laws, infectious salmon anemia will remain in perpetuity in Chile, embedded in an industry conditioned to monitor for it. The only question is, what new forms of disease will come to join it, and what ecological rubble will they leave behind? Will another virus be born, or will the levels of antibiotics being used to fight Rickettsia result in antibiotic resistance to quinolones and the invention of a super-bacterium that cannot be fought with current medicine? And what would such a bacterium do to local salmon farmers?

Humans and non-humans are simultaneously intelligible both as a part of nature and apart from nature. They go from actors, to objects acted upon by nature, and back to actors in an endless cycle. Chilean workers, Piscirikettsia, infectious salmon anemia, and salmon themselves, as organisms, are both agents and objects. The Humboldt Current, Chilean coastlines, and plastic salmon pen tubing also function as agents and objects. They have a dual nature, and as Bruno Latour says, operate in "hybridized collectivities" (Latour 1999). But the implications of our changes are very different depending on the contingencies of history, and the human and non-human potentials they muster.

Salmon farms are petri dishes, and the fjords of southern Chile, a laboratory. This laboratory of farms has brought pandemic salmon flu, which is in Chile to stay. To call Chile's ISA, which wiped out 20,000-60,000 jobs and cost $\$ 2$ billion, 'natural', as the salmon farmers do, is to normalize and diminish the 
human agency and economy in creating this disease ${ }^{10}$ It removes responsibility from those who build the infrastructure of its incubation. Recent work in Norway by Heidrun Plarre suggests that natural reservoirs of ISA, while theoretically possible, are not significant in the recent evolution of ISA. No new strains of ISA have emerged from wild populations in the last twenty years, thus highlighting the role of salmon farming in manufacturing the disease. The mixing of these viruses in brood stocks, in hatcheries, among smolts, and in marine net pens is the source of all of the newer, and more virulent, strains (Plarre et al. 2012).

These super-virulent strains do not form in isolation; influenza viruses are density-dependent. ${ }^{11}$ As industrial salmon farming became a game of spending as little as possible to get salmon as large as possible, it became about keeping fish barely alive, just enough to get them to market in the United States. The significance of simultaneity among salmon diseases becomes hard to overstate. The dependence of piscirikettsia on salmon lice, and the dependence of ISA on both of them, defines a set of hybridized ecologies in action in these petri dishes of the sea. Sea lice transfer many salmonid viruses, including salmon flu, in ecological webs far more complex, and far less understood. ${ }^{12}$ Each of these have agency in the narrative.

New disease outbreaks depend on many fish together in close quarters. The more pests and pathogens the fish can interact with, the more chance the mutations of different proteins in the genotypes of different diseases have to mix and match among them and mutate further. Yet, amidst the bacteria, the lice, the flus, and other viruses, in intensive agricultural systems there is one other organism upon which they all codepend: Homo sapiens. Remove humans from the equation, and these disease clusters fall apart. But so does the ability to work new jobs, and fly fresh salmon to northern dinner tables.

Only by detailing the many agencies in the Chilean salmon farming narrative can historians accurately depict the variety of actors involved and the complexity of their involvement in the cyclical failures of boom and bust industries. This does not reduce the human agency in the story; rather it enhances an awareness of the co-action of humans in concert with the non-human world in instigating reciprocal changes to the environment. By overstating their independence, and singular agency, social scientists risk reinforcing a narrative of a human ability to control the natural world. This ultimately supports technocratic narratives of the ability to control the future path of progress, rather than emphasizing the need for caution and for a full understanding of ecological factors. The view of high modernism endures amidst the boosters of salmon farming who argue that science and technology will be able to solve any problem that the booms and busts of industrial agriculture can create. As long as rickettsia exists, the need to develop a salmon vaccine against it will also exist, and new frontiers of production will remain attainable. More importantly, the modern delusion that humans can control the nonhuman world will continue, and humans will remain on "an endless environmental treadmill", blind to their inabilities as well as the burdens passed on to future generations, the ecological rubble of new diseases, lost cultures, crashing populations of native species, insecure jobs, polluted coastlines, and new forms of antibiotic resistance. ${ }^{13}$

Ecological rubble appears in many forms in Chile. It appears alive, as the pink flesh of the normally white-fleshed robalo (cusk-eel) that eat the excess pigmented cataxanthin salmon feed around the pens. Or as the local Galaxiidae sp. fish (puye) displaced by reproducing colonies of escaped steelhead salmon taking over native streams in Chiloé. It surfaces through the carcasses of dead salmon killed by an invasive and deadly virus inadvertently delivered to Chile by a shipment of Norwegian salmon eggs and covered up by

\footnotetext{
${ }^{10}$ Estimates vary about how many jobs were lost. The maximum number of direct jobs the industry created was 40,000 in late 2008, ironically peaking at the height of ISA created by the need to harvest fish early who would otherwise die unsold. Subcontracted employment is widespread, however, and hard to estimate.

${ }^{11}$ The 1918-1919 flu epidemic in northern France is thought to have been the result of high densities of many different people clustered in hospitals and trenches (Crosby 2003; McNeil 1998).

${ }^{12}$ Nylund et al. found that salmon infested by sea lice copepods can receive the salmon flu from other fish species such as saithe (1993). More recently, correlations of well-known diseases with ISA virus are now being described, with the dependence in Chile of infectious pancreatic necrosis (IPN) on ISA now demonstrated. IPN is the most costly salmon disease worldwide. A recent study indicated that of 43 Atlantic salmon that were salmon flu positive, IPN virus coinfected $86.1 \%$ of them. In contrast, only $6.7 \%$ of the samples that were without salmon flu had IPN virus (Overstreet et al. 2009).

${ }^{13}$ The phrase is Stuart McCook's (2001: 101).
} 
state and industry actors. In 2016, it appeared in the 100,000 metric tons of dead salmon asphyxiated by a red tide, as well as the cysts of the red-tide fomenting Alexandrium catanella dinoflagellates benefiting from the surfeit of excess nitrogen dumped into Chiloé's inner seas by salmon farming. And it may yet appear through the inexplicably diminishing populations of the Hudsonian Godwit (Limosa haemastica), a bird that breeds in Alaska but overwinter in Chiloé. Hudsonian Godwits make that tremendous migratory flight every year, alongside airplanes flying fresh salmon to northern dinner tables, but now there are concerns that its population reductions are linked to salmon farming activities in Chiloé (Delgado et al. 2010).

This article has argued that until ecological rubble, in the form of these non-human actors, is given agency in historical narratives, the politician, the scientist, and the social scientist alike will take too much credit for causing and controlling these booms and busts, and the historian will give it to them. Trapped by inaccurate renderings that reinforce assumptions of human control over the natural world, these simple narratives blind us to serve the very people who profit from environmental harm. Only a type of sea rubble, nearly invisible to us, will remain, bobbing like an abandoned salmon pen, until it breaks free and falls below our horizon to a barren bottom.

\section{References}

Aquanoticias. 2001. No existe anemia infecciosa. September 20. [Accessed December 1, 2014]

Aquanoticias. 2009. Opinión: Virus ISA, ¿contagiará a Noruega, al Estado de Chile...? August 3. [Accessed June 3, 2010]

Asche, F., H. Hansen, R. Tveterås and S. Tveterås. 2010. The salmon disease crisis in Chile. Marine Resource Economics 24(4): 405-411.

Banco Central de Chile. 2016. Baso de datos estadísticos. [Accessed March 30, 2015]

Bluth, A., L. Espinosa, C. Guzmán, C. Hidalgo, S. Martínez, M. Mellado, V. Sánchez, and M. Tang. 2003. La acuicultura en Chile/Aquaculture in Chile. Santiago: TechnoPress.

Brantz, D. 2011. 'Risky business': disease, disaster and the unintended consequences of epizootics in eighteenth-and nineteenth-century France and Germany. Environment and History 17(1): 35-51.

Crosby, A. 2003. America's forgotten pandemic. Cambridge: Cambridge University Press.

Curran, D. 2013. Risk society and the distribution of bads: theorizing class in the risk society. The British Journal of Sociology 64(1): 44-62.

Delgado, C., M. Sepúlveda, and R. Álvarez. 2010. Conservation plan for migratory shorebirds in Chiloé. Executive Summary. Valdivia: Western Hemisphere Shorebird Reserve Network. [Accessed August 11, 2016]

Diario Financiero. 2016. Gobierno endurece norma que limita producción de salmoneras y firmas presentan reclamos. June 2. [Accessed June 23, 2016]

Dumit, J. 2012. Drugs for life: growing health through facts and pharmaceuticals. Durham: Duke University Press.

El Ciudadano. 2009. Contra la persecución de Bachelet a los defensores del mar. August 23. [Accessed October, 1, 2010] http://www.elciudadano.cl/2009/08/23/10659/contra-la-persecucion-de-bachelet-alos-defensores-del-mar/

Esposito, A. 2015. Addicted to antibiotics, Chile's salmon flops at Costco, grocers. Reuters. July 23. [Accessed August 8, 2015]

FAO. 2016. Global aquaculture production database. FAO Fisheries and Aquaculture Department. [Accessed June 11, 2016].

Franklin, J. 2016. Toxic 'red tide' in Chile prompts investigation into salmon farming. The Guardian. May 17. [Accessed June 20, 2016]

Gerhart, A. 2012. Chile's aquaculture industry. Spatial History Project, Stanford University. [Accessed August 8, 2016]

Giddens, A. 1999. Risk and responsibility. The Modern Law Review 62(1): 1-10. Scribd 
Godoy, M., M. Aedo, M. Kibenge, D. Groman, C. Yason, H. Grothusen, A. Lisperguer, M. Calbucura, F. Avendaño, M. Imilán, M. Jarpa and F. Kibenge. 2008. First detection, isolation and molecular characterization of infectious salmon anaemia virus associated with clinical disease in farmed Atlantic salmon (Salmo salar) in Chile. BioMed Central Veterinary Research 4: 28.

Gordillo, G. 2014. Rubble: the afterlife of destruction. Durham N.C.: Duke University Press. Academia, intro Hayward, P. 2011. Salmon aquaculture, cuisine and cultural disruption in Chiloé. Locale: The AustralasianPacific Journal of Regional Food Studies 1: 87-110.

Hoelle J. 2017. Jungle beef: consumption, production and destruction and the development process in the Brazilian Amazon. Journal of Political Ecology 24: 743-762.

Hosono A., M. Iizuka and J. Katz (eds.). 2016. Chile's salmon industry: policy challenges in managing public goods. Dordrecht: Springer.

Howard, B.C. 2015. 337 whales beached in largest stranding ever. National Geographic. November 20. [Accessed June 20, 2016].

Klubock, T.M. 2014. La frontera: forests and ecological conflict in chile's frontier territory. Durham: Duke University Press.

Latour, B. 1999. Pandora's hope: essays on the reality of science studies. Cambridge: Harvard University Press.

Lizana, F.V. 2016. ¿La investigación científica chilena será capaz de aportar soluciones a la crisis en Chiloé? Ciperchile.cl. May 10. [Accessed July 20, 2016]

Mardones, F.O., A. Perez, P. Valdes Donoso and T. Carpenter. 2011. Farm-level reproduction number during an epidemic of infectious salmon anemia virus in southern Chile in 2007-2009. Preventive Veterinary Medicine 102: 175-84.

McCook, S. 2002. States of nature: science, agriculture, and environment in the Spanish Caribbean, 17601940. Austin: University of Texas Press.

McCook, S. 2011. The neo-Columbian exchange: the second conquest of the greater Caribbean: 1720-1930. Latin American Research Review 46(suppl.): 11-31.

McNeil, W. 1998. Plagues and peoples. New York: Anchor Books.

Mitchell, T. 2002. Rule of experts: Egypt, techno-politics, modernity. Berkeley: University of California Press.

Norwegian Institute of Public Health. 2009. Forbruk av Legemidler i Norsk Fiskeoppdrett i 2001-2008 (Consumption of drugs in Norwegian Fish Farms 2001-2008). [Accessed May 8, 2014]

Nylund A., C. Wallace and T. Hovland. 1993. The possible role of Lepeophtheirus salmonis (Krøyer) in the transmission of infectious salmon anaemia. In Boxshall G. and D. Defaye (eds.) Pathogens of wild and farmed fish: sea lice. London: Ellis Horwood.

NRC Handelsblad. 2009. Controversial flu expert receives 1 million euro grant. October 22. [Accessed March 11, 2016]

Osterhaus, A. 2001. Catastrophes after crossing species barriers. Philosophical Transactions: Biological Sciences 356 (1410): 791-793.

Overstreet, R., J. Jovonovich, and M. Hongwei. 2009. Parasitic crustaceans as vectors of viruses, with an emphasis on three penaeid viruses. Integrative and Comparative Biology 49(2):127-141.

Plarre, H., A. Nylund, M. Karlsen, Ø. Brevik, P.A. Sæther, and S. Vike. 2012. Evolution of infectious salmon anaemia virus (ISA virus). Archives of Virology 157(12): 2309-2326.

San Martín, W. 2017. Nitrogen, science, and environmental change: the politics of the green revolution in Chile and the global nitrogen challenge. Journal of Political Ecology 24: 777-796.

Santiago Times. 2009. Chile: police raid homes of salmon industry heads. August 19. [Accessed December 2 , 2013]

Sonu, S. 1995. The Japanese Sea Urchin market. NOAA Technical Memorandum.

Stanford-Rimisp Survey. 2009. Survey of salmon farming in central Chiloé. Unpublished. 
Tinsman, H. 2014. Buying into the regime: grapes and consumption in cold war Chile and the United States. New Brunswick, N.J.: Rutgers University Press.

Undercurrent News. 2016. Salmon crisis, red tide to double unemployment in southern Chilean region. May 30. [Accessed June 20, 2016]

Winslow, A. and A. Gerhart. 2011. Social unrest surrounding Chilean aquaculture, 2000-2010. Spatial History Lab, Stanford. [Accessed August 8, 2016]. 